\title{
The diagnostic value of polarographic serum reaction
}

\author{
By A. KočENT \\ From the Cancer Research Institute, Department of Biochemistry, Brno, Crechoslovakia (Chief: RNDr Z.Brada, C.Sc.)
}

(Eingegangen am 22. August 1966)

The WALDSCimidT-LerTz modification of the polarographic Brditka reaction yields results that are almost identical with the original reaction. After taking into consideration some carlier studies concerning other modifications, it may be presumed that not a modification can produce information different from that given by the Brdička reaction, because the composition of the solutions after deproteinisation is identical or nearly so. Since our present knowledge of the composition of filtrates is rather scanty, we cannot expect polarographic analysis to be suitable for differential diagnosis. The reaction is merely a non-specific test for demonstrating an increase or decrease of glycoproteins in the serum. The polarographic determination of proteins can, however, be used to the best advantage in tests based on the proteolytic activity of some enzymes in the serum.

Die von WaldSCHMidT-Lerrz eingeführte Modifikation der polarographischen Brdička-Reaktion führt zu Resultaten, die mit denen der Originalreaktion fast identisch sind. Aus der Betrachtung einiger früherer, andere Modifikationen betreffende Arbeiten kann geschlossen werden, daß keine einzige Modifikation Informationen geben kann, die von denen der Brdička-Reaktion verschieden sind, da die $\mathrm{Zu}$ sammensetzung der Lösungen nach Enteiweißung stets die gleiche oder fast die gleiche ist. Da unser gegenwärtiges Wissen von der Zusammensetzung der Filtrate unzulänglich ist, können wir nicht erwarten, daß die polarographische Analyse für eine Differential-Diagnose geeignet ist. Die Reaktion stellt lediglich einen unspezifischen Test dar, der eine Zunahme oder Abnahme der Glykoproteine im Serum anzeigt. Die polarographische Proteinbestimmung kann immerhin erfolgreich bei Testen eingesetzt werden, die auf der proteolytischen Aktivität einiger Serumenzyme betuhen.

By the polarographic serum reactions are meant polarographic methods that make use of the catalytic double wave of proteins in the presence of $\mathrm{Co}^{+++}$-complexes in ammonium buffers. They are derived from, or are identical with the Brdickea non-filtrate reaction (1) of 1937, or more frequently with the Brdickea filtrate reaction (2) of 1938. This reaction or its modifications are also called "polarographic serum filtrate reaction" or "polarographic filtrate test", etc. Initially, the Brdickea reaction was to replace cancer tests based on the estimation of the activity of sulphhydryl groups, either direct in the serum or during the action of proteolytic enzymes on the serum. For this reason, its earlier name was "cancer test", or "Krebsreaktion". However, it was later $(3,4)$ established that the reaction was not specific for cancer and that it also gave significantly positive results in inflammatory processes, in tuberculosis and other diseases, while in liver diseases, also in those of cancer origin, the wave heights obtained were lonver than those with normal sera.

The ease with which polarographic determinations can be performed and their high reproducibility have however brought about that the reaction is still used in clinical laboratories. A great deal of effort has been already exerted to raise the specificity of the Brdickea reaction for cancer or to make use of this reaction for differentiating other diagnostically similar diseases. The authors of some papers dealing with the Brdickea reaction have aimed at learning about the substantial basis of the reaction, while others have concentrated upon the empiric modification of the methodic conditions, on more effective ways of evaluation, or on the combination of several modifications. The most frequently used modifications are: denaturation by boiling the sera according to WALDSCHMIDT-LEITZ (4), comparison of the double wave with the zinc maximum according to Hasselbach and Schwabe (5), and the "protein index" according to MüLLER and Davis (6). The recently published paper by BraUn and KRATZSCH
(7) has proposed to combine the WALDSCHMIDT-LEITZ method with that of HASSELBACH.

Since we have devoted a great deal of attention to the Brdickea reaction and its modifications, we should like to give an account of our experience with the above mentioned modifications and to express our views on the possible prospects of success when using these modifications. In one of our earlier papers (8) we have given a critical evaluation of the protein index and of the HASSELBACH modification, while in the present paper we wish to submit some results obtained when checking the WALDSCHMIDT-LEITZ modification.

\section{Material and Methods}

A polarograph type 8 "Nejedlỳ" with a galvanometer of a sensitivity of $2.05 \times 10^{-9} \mathrm{~A} / \mathrm{mm}$ was used. The sensitivity was in all experiments reduced to $1 / 300$. The cathode was a capillary tube with a flow rate of mercury of $4.18 \mathrm{mg} / \mathrm{sec}$. and a drop time of $2.66 \mathrm{sec}$. at a reservoir height of $40 \mathrm{~cm}$. The anode was a silver wire. The solutions'were polarographed in small test-tubes in the presence of air.

The reactions were carried out with sera from patients of the "Cancer Institute" in Brno, while the sera of healthy persons were obtained from the "Blood Transfusion Centre" in Brno.

Polarographic reaction was performed according to the following three methods: a) the WALDSCHMIDT-LeITZ modification $(4,7)$; b) the original Brdickea reaction $(2,9,10)$; c) reaction without alkali denaturation (our own modification). The last was carried out in the following way: $0.4 \mathrm{~m} l$ of serum $+1 \mathrm{~m} l$ saline solution + (immediately) $1 \mathrm{~m} l 1 \mathrm{~N}$ sulphosalicylic acid. After ten minutes the precipitate is removed with a filter paper Whatman No. 1 (11), the diameter of the unfolded filter being $5.2 \mathrm{~cm}$. Then $0.4 \mathrm{ml}$ of the filtrate is diluted with $4 \mathrm{ml}$ of cobalt buffer composed of $10^{-3} \mathrm{MI}$ $\mathrm{Cc}\left(\mathrm{NH}_{3}\right) \mathrm{Cl}_{3}, 0.1 \mathrm{M} \mathrm{NH}_{4} \mathrm{Cl}$ and $1 \mathrm{M} \mathrm{NH}_{4} \mathrm{OH}$.

A comparison of the parameters of all three polarographic reaction is given in table 1 .

The results of the individual modifications were statistically evaluated and mutually compared with the help of a digital computer type LPG 30.

\section{Results}

\section{The influence of sulphosalicylic acid concentration}

All three modifications were carried out at different sulphosalicylic acid concentrations in such a manner as 
Tab. 1. Comparison of methods of some polarographic tests

\begin{tabular}{|c|c|c|c|c|}
\hline Modification & Serum denaturation & $\begin{array}{c}\text { Sulphosalicylic acid concentration } \\
\text { during deproteinization }\end{array}$ & & $\begin{array}{l}\text { Serum dilution } \\
\text { in the filtrate }\end{array}$ \\
\hline $\begin{array}{l}\text { WALDSCHMIDT-LEITZ } \\
\text { BRDICKA } \\
\text { Without alkali }\end{array}$ & $\begin{array}{l}\text { boiling } 10 \mathrm{Min} \\
0.1 \mathrm{M} \mathrm{KOH} ; 45 \mathrm{Min}\end{array}$ & $\begin{array}{l}1 \mathrm{~N} \text {, i. e. } 12.5 \% \\
0.67 \mathrm{~N} \text {, i. e. } 8.33 \% \\
0.42 \mathrm{~N} \text {, i. e. } 5.2 \%\end{array}$ & & $\begin{array}{l}1 / 6 \\
1 / 6 \\
1 / 6\end{array}$ \\
\hline Relationship & $\begin{array}{l}\text { for normal sera } \\
19 \text { cases }\end{array}$ & $\begin{array}{c}\text { Correlation } \\
\text { for pathological sera } \\
49 \text { cases }\end{array}$ & for the & $\begin{array}{l}\text { ole group } \\
\text { ases }\end{array}$ \\
\hline $\begin{array}{l}\text { WALDSCHMIDT-LEITZ/reaction } \\
\text { without alkali }\end{array}$ & 0.339 & 0.772 & 0.795 & \\
\hline WALDSCHMIDT-LEITZ/BRDIČKA & 0.831 & 0.894 & 0.907 & \\
\hline BRDIČKA/reaction without alkali & 0.493 & 0.810 & 0.827 & \\
\hline
\end{tabular}

In frames - the significance of some differences. $P$ stands for the probability that the observed difference in the correlation coefficients would be only accidental.

to obtain successive concentration of $1 \mathrm{~N}, 0.67 \mathrm{~N}$ and $0.42 \mathrm{~N}$ in the filtrate. Such an experiment is shown in Figure 1, from which it follows that the height of the wave falls with the decrease in the concentration of sulphosalicylic acid. It has been demonstrated that the wave heights of the Brdicka reaction and of the WALDSCHMIDT-LEITZ reaction are practically equal at the same concentration of the sulphosalicylic acid, but they are not equal when the reactions are carried out according to instructions (see Methods), as can be seen when comparing curves $1 \mathrm{a}, 2 \mathrm{~b}$ and $3 \mathrm{c}$ in Figure 1 .

\section{Clinical experiment}

All the three modifications were applied in the case of 19 normal sera and of 49 sera obtained from patients mostly suffering from tumour disease. A comparison of the wave heights of the modifications carried out is illustrated in Figure 2, while the correlation coefficients are given in table 2 . It is evident that the closest relation exists between the WALDSCHMIDT-LEITZ modification and the Brdicka reaction in which case the correlation coefficient amounts to 0.91 . The correlations for the group of normal persons are lower than those for the tumour bearing patients, the difference being significant for the relation Brdicka reaction /reaction without alkali $(\mathrm{P}<5 \%)$ and for the relation WALDSCHMIDT-LeItz modification / reaction without alkali / $\mathrm{P}<2 \%$ /.

\section{Discussion}

\section{Comparison of the modifications}

The protein index is - according to the definition $\mathrm{PI}=\left(\mathrm{h}_{\mathrm{r}} / \mathrm{h}_{\mathrm{n}}\right) \cdot 15$ - actually the ratio of wave heights of the filtrate and non-filtrate Brdickea reaction. In addition to eliminating the capillary parameters, the protein index was also to contribute to improving the resolution power of the polarographic reaction. After closer examination it is, however, evident that the $h_{n}$ in the fraction's denominator changes only slightly, and almost in all cases in the opposite sense than $h_{f}$ does, so that the PI value is predominantly determined by the filtrate reaction.
This conclusion has also been confirmed experimentally (8) and a high correlation coefficient of 0.96 has been established. Nor is the differentiation of notmal sera from pathological ones better $(8,12)$ than with the original Brdicka reaction.

In the case of the Hasselbach and Schwabe modification the height of the polarographic maximum above the common cobalt and zinc wave is compared with the height of the protein wave of catalytic origin. Both polarographic processes, although of a different mechanism, are regulated by the same factor, namely by protein concentration. When the latter rises, the maximum falls, and the height of the catalytic double wave rises. For this reason, when statistically evaluating this case, we have found a high correlation coefficient between the height of -the maximum and the Brdickea reaction ( $r=0.97$ ), as well as between the heights of the double waves of the Brdicke reaction and the HASSEL$\mathrm{BACH}$ modification $(\mathrm{r}=0.96)$ (8). Owing to these results the difference between the maximum and protein double wave in HaSSELBACH modification must correlate closely with the Brdickea reaction.

Finally, in this study we compared the WALDSCHMIDTLEITZ modification, in which the serum is partly denatured by boiling, with the Brdickea reaction, in which denaturation is effected by alkali. Since the height of the wave in the WALDSCHMIDT-LEITZ modification is always higher than that of the Brdickea reaction, it might be expected that denaturation by boiling would lead to a release of a greater amount of polarographically active components, or that it would favourably influence deproteinization with sulphosalicylic acid, for it is known (3) that the precipitate of sulphosalicylic acid with proteins "intercepts" the polarographically active substances. However, it has been demonstrated in our results that the observed increase in the wave is due only to the higher concentration of sulphosalicylic acid during deproteinization. Such an increase in the filtrate wave has been already observed earlier (13) and found to be associated with raised protein solubility in a sulphosalicylic acid medium, for at a concentration 
Fig. 1

Influence of the molarity of sulphosalicylic acid during deproteinization on the height of the wave. Curves 1: WALDSCHIMIDT-LEITZ modification; curves 2: BRDIčKA reaction; curves 3: reaction without alkali denaturation; curve 4: cobaltic buffer solution. Concentration of the sulphosalicylic acid in filtrate: $a: 1 \mathrm{~N} ; b: 0.67 \mathrm{~N} ; \mathrm{c}: 0.42 \mathrm{~N}$

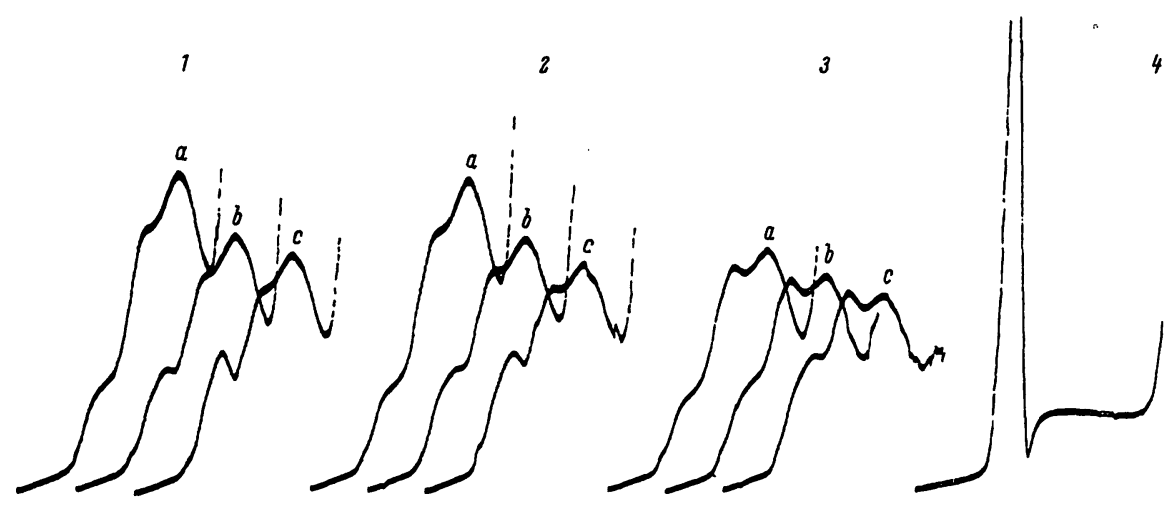

of $5.8 \mathrm{~N}$ of sulphosalicylic acid in the filtrate proteins do not precipitate at all (14). In the case of the WALDSCHMIDT-LEITZ modification, the filtrate is consequently enriched by proteins that should remain on the filter as insoluble. Otherwise, the composition of the filtrate is probably similar to that in the Brdickea reaction, because the correlation coefficient of the two reactions amounts to 0.91 .

It is rather surprising that in spite of great interference, such as leaving out deproteinization, boiling prior to deproteinization, or comparing the double wave with the polarographic maximum, the correlation of these modifications with the Brdicka reaction remains close, whereas a seemingly slight interference, such as the omitting of alkali denaturation, results in a significantly looser relation (see $\mathrm{P}$ values in table 2 ). In addition to a decrease in the correlation from 0.91 to 0.80 in relation to the WALDSCHMIDT-LEITZ modification a correlation coefficient $r=0.83$ for 68 cases has been found between the Brdicka reaction and the modification without alkali. This coefficient agrees well with values obtained earlier, namely 0.87 for 137 observations (9) and 0.84 for 35 observations (11), the differences being statistically nonsignificant. The explanation of almost complete correlation of the Brdicka reaction for the protein index and the HASSELBACH modification lies in the fact that the size of the evaluated quantity is determined by the amount of proteins in the sulphosalicylic filtrate, which is in both cases prepared in the same way as in the Brdicka reaction. The filtrate of WALDSCHMIDT-LEITYZ modification contains a greater amount of proteins, but denaturation by boiling perhaps releases substances of a similar character as those released during denaturation with alkali, and consequently the correlation coefficient remains fairly high.

On the other hand, the modification without alkali differs from the above modifications in having filtrates containing fewer non-mucoproteins substances (9). The filtrates are relatively richer in mucoproteins than the filtrates of the other modifications. Consequently they differ more in their composition, which is also reflected in the correlation, in particular in the case of healthy persons (see Fig. 2). The phenomenon that the correlations of the various parameters are higher in pathological than in normal sera has also been reported in another study (15) dealing with the role of the liver in muco-
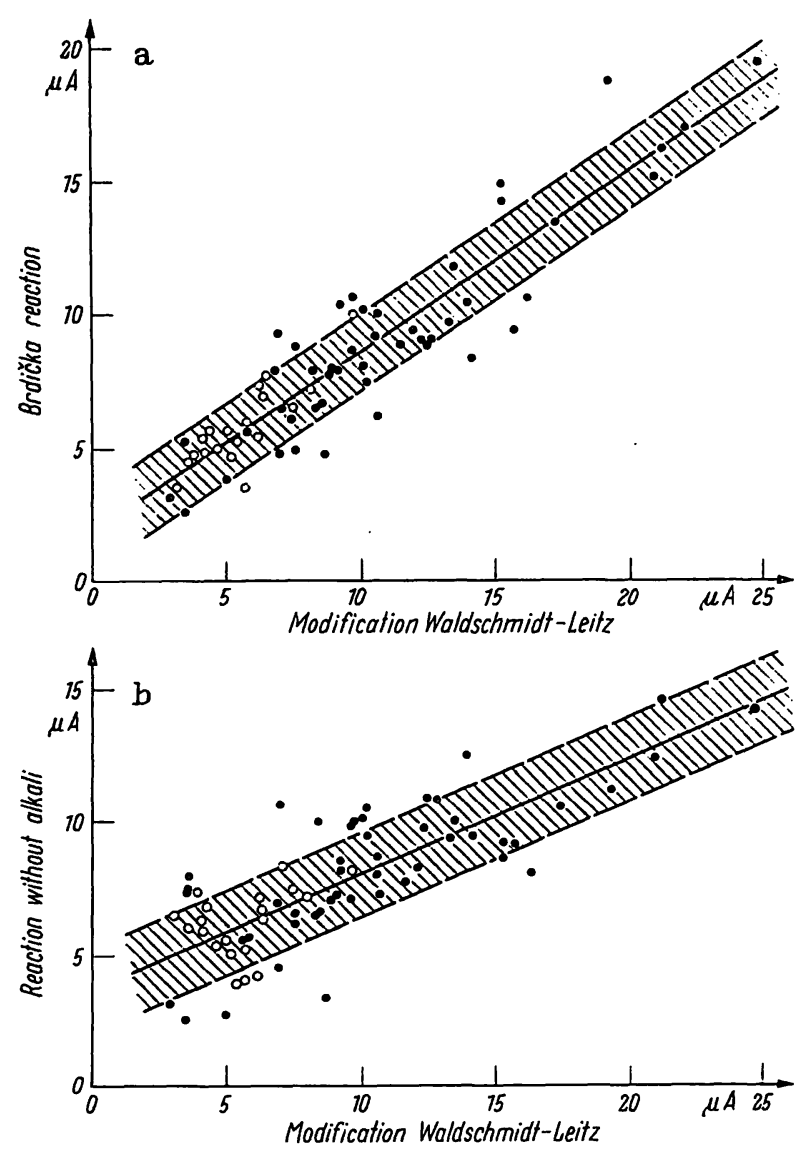

Fig. 2

Correlation between modifications: a: WALDSCHMIDT-LEITZ modification and BRDIčKA reaction; b: WALDSCFarrdT-LEITZ modification and reaction without alkali denaturation.

o normal sera; pathological sera. Fully: regression line, dotted : deviation round the regression line

protein synthesis in tumour-bearing rats. It is apparently connected with the fact that raised muco- and glycoprotein concentrations cover up the differences observed in normal sera.

The modification without alkali has, however, not been created for clinical purposes, and with regard to the size of the correlation coefficient with the Brdickea reaction it cannot even be expected to yield markedly different results. The modification is, however, advantageous for the polarographic study of mucoproteins (15) and for this purpose it is more suitable than the Brdicka filtrate reaction. 
The substantial basis of polarographic tests To judge the diagnostic possibilities it would.be an advantage to know the composition of the solution to be polarographed and its main polarographically active components. Initially, Brdicka presumed (16) that polarographic activity was due to those aminoacids of proteins that contained sulphhydryl or disulphide groups. MAYER (17) reported that the filtrate contained negligible amount of sulphur, and ascertained the presence of a substance of a mucoidic character. Later, mucoproteins were proved by free electrophoresis in filtrates after treatment with perchloric (18) and sulphosalicylic acid (19). And the Brdicka reaction is believed to be caused by mucoproteins.

When investigating this problem, it has been found (9) that the polarographic activity of the Brdickea filtrate reaction is due to mucoproteins to less than $50 \%$ while other substances are responsible for the rest of the activity. If denaturation with alkali is left out, the share of mucoproteins in the polarographic activity rises to $60-80 \%$. Further experiments $(20)$ have indicated that the polarographic activity of the non-mucoprotein components of the filtrate is connected with the sulphhydryl groups.

Five fractions, designated A, B, C, D, E (Fig. 3) have been found (21) on subjecting the filtrates to chromatography on DEAE cellulose. The biggest fraction $C$ contains most proteins, hexosamines and polarographically active substances. After treatment with alkali (compare elution profile $a$ and $b$ ) there follows a big polarographical increase in fraction $A$ and a small increase in fraction $C$, while the relative hexosamine content of fraction $\mathrm{A}$ and $\mathrm{B}$ falls; consequently, they are enriched with substances of a non-mucoprotein

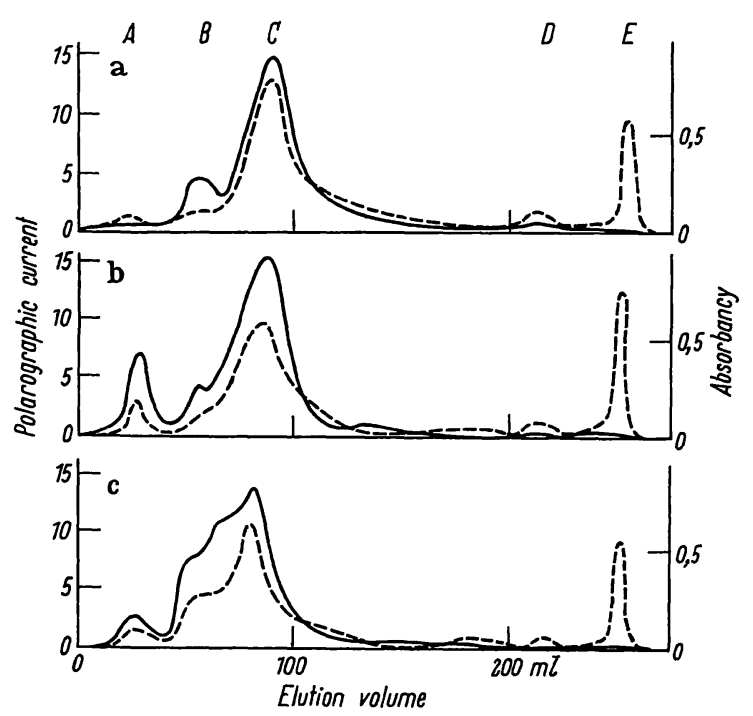

Fig. 3

Chromatography of the sulphosalicylic acid filtrate on a DEAEcellulose column. a: normal serum, reaction without alkali denaturation; b: normal serum, BRDIčKA reaction; c: cancer serum, BRDIČKA reaction.

- polarographic activity; -..-.-- hexosamine content character. In sera from patients with carcinoma (profilec) spreading and peak shoulder formation has been observed in fraction C. This fraction, however, also contains many non-mucoprotein substances because the relative participation of glycoproteins is less than in fractions $A$ and $B$.

When subjected to immunoelectrophoresis, the sulphosalicylic filtrates have so far yielded 5-9 components $(22,23)$ in human serum, and as many as 13 protein components in rat serum (24), out of 30 components demonstrated in the total serum (25). According to their electrophoretic mobility, the components belong to all fractions from prealbumins to $\gamma$-globulins. It may be hardly expected that all of them are glycoproteins, and or mucoproteins. For instance, BISERTE (22) has identified in the filtrate of human serum orosomucoid, $\alpha_{1}$-glycoprotein according to SCHULTZE, haptoglobin, hemopexin, and albumin. ANDERson (26) believes that albumin, prealbumin and $\gamma$-globulins pass into the filtrate, because glycoproteins act as a protective colloid during precipitation. However, the identification of a certain protein points more to detection possibilities than to its meaningful representation in the filtrate.

\section{Conclusions for diagnostics}

Since it has been proved that both the HASSELBACH and the WALDSCHMIDT-LEITZ modification are parallel with the Brdicka reaction, it can be hardly expected that the combination of both modifications as assumed by BRAUN (7), would yield other results than the Brdickea reaction itself. Some further modifications and other methods of evaluation have been tested (8), but the results have always been the same. PÚRDY (27), too, has arrived at the same conclusion in his review. Almost complete agreement with the Brdickea reaction and mostly much more laborious procedures give little hope for any diagnostic advances. Although several authors have reported in their studies some differences - sometimes even statistically proved - in the polarographic test for a certain pair of diseases, e. g. differentiation between tumour and tuberculosis $(28,29,30)$, or tumour and inflammation $(5,31)$; these differences could not be as a rule confirmed in later experiments. This fact seems to indicate that the differences observed are of an accidental character.

When attempting to rationally evaluate polarographic tests, it is necessary to proceed from hitherto gained knowledge of the origin of the double wave and filtrate composition. The double wave pertains to the reduction of hydrogen on the mercury drop electrode. Reduction takes place at a more positive potential than is the evolution potential of hydrogen on mercury, because it is catalysed by a complex of protein and cobalt. The doublepeak course of this catalytic reaction is probably due to some rather complicated mechanism (10). However, we can certainly exclude the assumption that each of the two protein waves corresponds to a certain functional group, e. g. mucoproteins and SH-group (32, 33). The catalytic double-wave is produced by substanices 
- if they are high-molecular - of a protein character. However, various proteins are not equally active. For instance, gelatine is not active at all, while the activity of many proteins increases with content of the sulphurcontaining amino-acids $(34,35,36)$. Other proteins, however, are active in spite of their very small or zero sulphur content, e. g. clupein or orosomucoid. In addition to the effect of the mobile hydrogen in the SH groups, it is also some hitherto unknown mechanism that comes into action during catalysis.

The polarographic activity of the sulphosalicylic filtrate is caused by a large number of proteins, none of which having a dominant position. The contingent diagnostic significance of a certain protein, e. g. haptoglobin, cannot be made use of, because the changes in its concentration are only slightly manifested in the total activity, which is the sum total of all the components of the filtrate. A considerable number of these protein components can be included in the group of mucoproteins and/or in the wider group of glycoproteins that apparently get into the filtrate owing to their resistance to moderately strong deproteinizing agents. The occurence of an increased mucoprotein amount in the serum is, however, such a frequent and non-specific phenomenon that it cannot serve as a very helpful diagnostic aid. A much more valuable indicator is the decrease in glycoproteins, which points to some damage to the liver parenchyma. However, a slight increase or decrease in mucoproteins may be masked by a reverse change in the filtrate's other components.

Consequently, the Brdicka reaction in all its modifications continues to have its significance as a non-specific clinical test for a change in the concentration of mucoproteins or glycoproteins in the serum. Some investigators have also considered the possibility of utilizing the reproducibility of the polarographic reaction, of following its value at longer time intervals, and of comparing it with the progress of the disease and the state of the organism. But these experiments have not yielded satisfactory results $(37,38)$.

Since polarographic tests are in good agreement with the amount of proteins in the filtrate, or in some other material, too, these reactions can be used in cases where protein concentration is diagnostically significant. This concerns the proteolytic properties of the serum. It is profitable, for instance, to determine polarographically the activity of pepsinogen for proving acblorbydria (39) or for demonstrating various diseases of the gastric mucous membrane (40), further the activity of catepsin (41) as an indicator of liver disease, or that of trypsininhibitor in the serum, or of trypsin in the duodenal juice (42).

The author wishes to express his thanks to Dr. Z. BraDA for useful suggestions and to Miss $Z$. Polakova for technical assistance.

\section{References}

1. BRDičKa, R., Nature (London) 139, 1020 (1937). - 2. BrdičKA, R., Acta intern. Ver. Krebsbekämp. 3, 13 (1938). - 3. BRDIčKA, R., F. V. Novík und J. KLumpar, Acta Radiol. Cancerol. Bohemoslov. Morav. 2, 27 (1939). - 4. WALDSCHMIDT-LEITZ, E. und K. MAYER, Hoppe-Seyler's Z. physiol. Chem. 261, 1 (1939). - 5. HasselBaCH, H. und K. Schwabe, Pharmazie 10, 310 (1955). - 6. Müller, O. H. und J. S. Davis, J. biol. Chemistry 159, 667 (1945). - 7. Braun, H. und K. H. Kratzsch, Clin. chim. Acta (Amsterdam) 11, 57 (1965). - 8. KočENT, A., Naoplasma (Bratislava) 5, 396 (1958). - 9. Kočent, A., Z. Brada und I. Boškova, Clin. chim. Acta (Amsterdam) 2, 508 (1957). - 10. BRDičKa, R., M. BrézinA und V. Kalous, Talanta (London) 12, 1149 (1965). - 11. KočENT, A., Thesis, Charles University Prague (1958). = 12. SrRICKs, W. und I. M. KolthofF, J. Lancet(Minneapolis) 73, 328 (1953). - 13. Kalous, V., Collect. Czechoslov. Chem. Commun. 21, 1236 (1956). - 14. Kočent, A. und I. Boškovi, Collect. Czechoslov. Chem. Commun. 22, 1665 (1957). - 15. TobišKA, J., Z. BrAdA, A. KočENT und Z. Pechan, Neoplasma (Bratislava) 11, 3,13 (1964). - 16. BrdrčKa, R., Acta Radiol. Cancerol. Bohem. Morav. 2,7 (1939). 17. MAYER, K., Hoppe-Seyler's Z. physiol. Chem. 275, 16 (1942). 18. Winzler, R. J., A. W. Devor, J. W. Mehl und I. M. Smyth, J. Clin. Invest. 27, 609 (1948). - 19. Kalous, V., Collect. Czechoslov. Chem. Commun. 19, 1039 (1954). - 20. KočEnt, A., to be published. - 21. KočENT, A., Unio int. Cancrum Acta 20, 951 (1964). - 22. Biserte, G,, R. Havez und A. Hayye-Levy, Clin. chim. Acta (Amsterdam) 5, 272 (1960). - 23. DoležAloví, V., Z. BRADA und A. KočEnt, Clin. chim. Acta (Amsterdam) 9, 542 (1964). - 24. Doležaloví, V., Z. Brada und A. KočEnt, Neoplasma (Bratislava) 11, 451 (1964). - 25. DoležAlovi, V., Z. BrADA und A. KočEnt, Biochim. biophysica Acta (Amsterdam) 107, 294 (1965). - 26. ANDERSON, A. J., Nature (London) 208, 491 (1965). - 27. Purdy, W. C., Analytic. Chem. 36, No. 4,29A (1964). -28. Balle-Helaers, F.., Ann. Biol. Clin. 14, 257 (1956). - 29. SASAI, T. und K. KuBo, Bull. Inst. Chem. Research (Kyoto) 36, 30 (1958). - 30. Jayle, M. F., J. Serpicelli und L. Robert, Clin. chim. Acta (Amsterdam) 1, 452 (1956). - 31. Orro, H. und E. BEYER, Dtsch. Gesundheitswes. 12, 687 (1957). - 32. SasAI, T., Bull. Inst. Chem. Research (Kyoto) 34, 321 (1956). - 33. MüLLER, O. H. und M. J. Elwood, Federat. Proc. 13, 340 (1954). - 34. Kalous, V. und Z.PAvL íčEK, Biochim. biophysica Acta (Amsterdam) 57, 44 (1962). - 35. LedvinA, M., Biochimija 21, 806 (1956). - 36. Mrllar, G. J., Biochem. J. 53, 393 (1953). - 37. Halder, G. E. und R. Steinhoff, Arch. Geschwulstforsch. 18, 21 (1961). 38. HAjJKovì, V., Thesis, University Brno (1961). - 39. JANOUŠEK, S., J. KrouLíkoví und F. MaLiš, Časopis lékařů čes. 94, 83 (1955). - 40. JaNoušEK, S., K. Herfort und J. ŠKaChovi, Českoslov. gastroenterol. 11, 167 (1957). - 41. HoMoLKA, J. und O. SoušEK, Časopis lékařů čes. 104, 941 (1965). - 42. НомоLkA, J., Časopis lékařů čes. 105, 268 (1966).

Dr. rer. nat. Alexandr Knčent. C. Sc., Brno, Z̈lutł́ kopec 7, Czechoslovakia 